\title{
Pore-Size and Water Activity Effects on Survival of Rhizobium tropici in Biochar Inoculant Carriers
}

\author{
Steven J Vanek ${ }^{1 *}$, Janice Thies ${ }^{1,3}$, Bing Wang ${ }^{2}$, Kelly Hanley ${ }^{1}$ and Johannes Lehmann ${ }^{1,3}$ \\ ${ }^{1}$ Soil and Crop Sciences, School of Integrative Plant Sciences College of Agriculture and Life Sciences, Cornell University, Ithaca NY, USA \\ ${ }^{2}$ State Key Laboratory of Environmental Geochemistry, Institute of Geochemistry, Chinese Academy of Sciences, Guiyang 550002, China \\ ${ }^{3}$ Atkinson Center for a Sustainable Future, Cornell University, Ithaca, NY 14583, USA
}

\begin{abstract}
Research examining biochar (pyrolyzed biomass) as a microbial inoculant carrier may enable broader use of inoculant microbes and elucidate relationships between non-spore forming bacteria, such as rhizobia, and their microhabitats in carriers and soils. We tested 32 biochars as habitat for Rhizobium tropici (CIAT 899) to quantify the effects of pore size distribution, chemical characteristics and clay addition on bacterial abundance, in both in sixmonth storage incubations at $27^{\circ} \mathrm{C}$, and under drying conditions. Pressure plate measurements and micrographic analysis yielded correlated estimates of mean macropore $(0.3-30 \mu \mathrm{m})$ size in the different biochar carriers $(r=0.80$, $p<0.0001)$. Macropore size was assigned to the first principal component of variation in biochar properties, along with mineral content derived from plant feedstocks. Under moist storage conditions, a number of biochars were equivalent to peat as microbial carriers. Rhizobium tropici abundance in these storage incubations exhibited a quadratic dependence on biochar pore size $(p<0.001)$ with maximal abundance at a macropore size of $13.6 \mu \mathrm{m}$ (pressure plate) or $10.1 \mu \mathrm{m}$ (micrographs). Abundance was lower for biochars with higher ASTM volatile content $(p<0.001)$ and was increased by plant feedstock derived mineral content in the biochars $(p<0.01)$. Goethite and Montmorillonite additions to biochar before pyrolysis increased macropores of size $<0.3 \mu \mathrm{m}$. Added Goethite reduced bacterial survival, while montmorillonite increased $R$. tropici abundance in a large-pored pine biochar by 10 times $(p<0.05)$, and improved its survival between two and 11 times $(p<0.001)$ in four biochars after drying for 10 days. We conclude that optimizing pore size distribution and chemical properties of biochars is a promising strategy to produce carrier materials that are as effective as mined irradiated peat for non-spore forming bacteria such as $R$. tropici.
\end{abstract}

Keywords: Rhizobium; Biochar; Inoculant carriers; Rhizobium tropici; Legumes; Phaseolus vulgaris; Microbial habitat

Abbreviations: ASTM: American Society for Testing and Materials; $\mathrm{A}_{\mathrm{w}}$ : Water Activity; CFU: Colony-Forming Units; EC: Electrical Conductivity; HTT- Highest Treatment Temperature; ICP-AES: Inductively Coupled Plasma: Atomic Emission Spectroscopy; PCA: Principal Components Analysis; PyOM: Pyrolyzed Organic Matter; YEM: Yeast Extract Mannitol; YMA: Yeast Mannitol Agar

\section{Introduction}

In comparison to mined peat inoculant materials, the use of widely available materials as microbial inoculant carriers could foster less expensive and more decentralized production and use of inoculant microbes to improve crop growth. By providing an appropriate habitat, inoculant carriers facilitate the transfer of important mutualistic microbes to soil or seeds at high densities, such as Rhizobium and Bradyrhizobium, as well as other non-spore forming bacteria that are especially vulnerable to drying and other stresses in soils [1]. The current industry standard carrier, irradiated peat, is a non-renewable resource that requires specialized equipment for manufacture [2,3]. Therefore, researchers have sought alternatives including organic polymers $[1,4,5]$, perlite [2], sugar industry waste press mud from sugarcane [6], and previous tests of charcoal [7-10] or pyrolyzed organic matter (PyOM), also referred to here as biochar.

If shown to be satisfactory as a bacterial carrier, biochar could have advantages over other materials since sterilization is accomplished by the pyrolysis process without the need for extra energy inputs related to autoclave operation or irradiation. To be comparable with peat carriers, a satisfactory substitute must maintain high rates of bacterial survival, e.g. $>10^{8}$ colony-forming units after six months of storage, as well as the ability to maintain bacteria in a viable state when applied under drying conditions in soils [1]. In this regard, biochar has some promising similarities to sterile peat, the industry standard carrier Like peat, biochar is a porous, persistent organic material that contains some fraction of mineral constituents, and a proportion of easily mineralizable organic matter that microbes may use to complement other substrates that are generally added to inoculant carriers. Along with biochar, another promising alternative to irradiated peat is sterilized sugarcane press mud from the sugar industry [11]. Like peat and biochar, press mud contains recalcitrant structural carbohydrates (lignified stems) and minerals from the soil that adheres to sugarcane during harvesting, but unlike peat and biochar it also contains highly available sugars. All three potential carrier materials show promise in supporting populations of inoculant microbes as a moist powder. In the pores of these powders, as in soils, microbes are thought to exist on surfaces within water films as sparse or "unsaturated" biofilms [12]. Along with the sterilization inherent in pyrolyzing plant biomass, an additional advantage to biochar as a carrier material would be the ability to use feedstock and process conditions to adjust its characteristics to match microbial needs for survival, once these optimal properties are known. Little basic research has examined the properties that maximize biochar's ability to host microbes [10]. Meanwhile studies of bacterial interactions with soil microsites that support bacterial survival [12-14],

*Corresponding author: Steven J Vanek, Soil and Crop Sciences, School of Integrative Plant Sciences College of Agriculture and Life Sciences, Cornell University, Ithaca NY, USA, Tel: +1 607-255-5241; E-mail: sjv13@psu.edu

Received June 04, 2016; Accepted June 29, 2016; Published July 09, 2016

Citation: Vanek SJ, Thies J, Wang B, Hanley K, Lehmann J (2016) Pore-Size and Water Activity Effects on Survival of Rhizobium tropici in Biochar Inoculant Carriers. J Microb Biochem Technol 8: 296-306. doi: 10.4172/1948-5948.1000300

Copyright: $\odot 2016$ Vanek SJ, et al. This is an open-access article distributed under the terms of the Creative Commons Attribution License, which permits unrestricted use, distribution, and reproduction in any medium, provided the original author and source are credited. 
as well as studies of bacterial survival in industrially-produced materials [15] suggest that both pore size and chemical properties such as the availability of labile carbon [16] are important in promoting bacterial survival. However no previous studies have systematically explored the properties of biochar and how these might promote or detract from the survival of microbes, such as rhizobia, that do not form durable resting spores [17]. Understanding which characteristics of biochar best support the survival of beneficial soil microbes such as Rhizobium is an important step towards more widely available, effective biochar carriers that equal the performance of peat and press mud. Understanding these characteristics may also illuminate aspects of how biochars function as bacterial microsites in soils [17].

To address gaps in our knowledge about bacterial survival on biochars, we investigated the interactions of PyOM properties and survival of Rhizobium tropici in biochar powder inoculant carriers. The objectives of the study were (i) to compare the survival of $R$. tropici on biochar carriers with survival on conventional inoculant carriers; (ii) to identify chemical and physical properties that control survival of $R$. tropici in incubations under typical storage conditions; and (iii) to identify biochars that would allow maximal survival of these bacteria under drying conditions that can occur after inoculant application. We hypothesized that (i) we could identify biochars with equivalent performance to industry standard carriers made from peat; (ii) chemical contents of biochars (e.g., volatile organic material, mineral content) would be the more important determinants of survival under less stressful storage conditions; and (iii) water retention, which is inversely related to biochar pore size, would be a major determinant of $R$. tropici survival under drying conditions.

\section{Materials and Methods}

\section{Experiment overview}

Incubation experiments tested these hypotheses, using $R$. tropici strain CIAT 899 inoculated into 28 powdered biochars prepared to resemble standard peat-based inoculant carriers. These biochars were chosen to vary widely in chemical characteristics and mean pore diameter, since these were hypothesized as the main determinants of bacterial survival. Principal components analysis (PCA) was used to summarize covariation of the wide range of biochar properties among biochar carriers. We conducted a set of preliminary trials to find approximate ranges of pyrolysis temperatures, nutrient feeding rates, and clay addition (for altering biochar pore size) to achieve microbial abundances in biochar carriers similar to those in a peat carrier. A full set of biochars was then tested under low-stress storage conditions similar to those of moist soils and a temperature typical of inoculant supply chains without refrigeration $\left(27^{\circ} \mathrm{C}\right)$. A second set of experiments tested bacterial survival under reduced water content during drying of the carrier materials tested. Both trials are described in detail below.

\section{Biochar and control bacterial carrier materials}

Biochars for incubations were made from 14 feedstocks ground prior to pyrolysis to pass through a $2 \mathrm{~mm}$ size sieve. These feedstocks were white pine (Pinus strobus), Douglas fir (Pseudotsuga menziesii), mixed maple (Acer rubrum, A. saccharum), mixed hardwood (Carya ovata, Acer spp.), Holly (Ilex americana); poplar (Liriodendron tulipifera), oak (Quercus rubra), grapevine (wild grape, Vitis riparia), maize stover (Zea mays); sugar cane bagasse (Saccharum officinarum), rice straw (Oryza sativa), hazelnut shells (Corylus avellana), water hyacinth (whole plants from Lake Victoria, Kenya; Eichornia crassipes) and rice hulls (Oryza sativa). These materials were converted to biochar in a custom pyrolysis unit comprising a closed, mild steel drum (6-mm walls) with a central rotating paddle driven at 1 RPM. The unit was installed into a programmable muffle furnace (Fisher Isotemp 126, Pittsburgh, PA, USA) programmed to maintain $450^{\circ} \mathrm{C}$ for $1 \mathrm{~h}$ after ramping $3^{\circ} \mathrm{C} \mathrm{min}{ }^{-1}$, with $1 \mathrm{~L} \mathrm{~min}^{-1}$ argon sweep gas. For initial trials to assess the best pyrolysis temperature for producing biochar carrier materials, $700^{\circ} \mathrm{C}$ was also used as a highest treatment temperature (HTT) with the same ramp rate and sweep gas. Resulting biochars were dry-sieved through $149 \mu \mathrm{m}$ and $75 \mu \mathrm{m}$ sieves, with the remnants from sieving reground until $100 \%$ of the material passed the $149 \mu \mathrm{m}$ sieve and $50 \%$ by weight passed through the $75 \mu \mathrm{m}$ sieve. These powder size specifications were identical to those we measured for dry-sieved peat used as the control carrier in these trials. Sugarcane press mud was obtained from MEA Fertilizer Company (MEA BIOFIX inoculant carrier material, MEA Fertilizers, Nakuru, Kenya). In the trials biochars were either used without modification (unmodified, $\mathrm{pH}$ adjustment only) or after washing with acetone, $1.0 \% \mathrm{HCl}$, or both (detailed for experiments below), to remove acetone-soluble organic constituents and easily soluble ash minerals. Washing was conducted by shaking carrier powders $8 \mathrm{~h}$ in $3: 1 \mathrm{v}$ : $\mathrm{v}$ suspensions and then rinsing $(3 \mathrm{x})$ in a Büchner funnel with qualitative filter paper (Whatmans, GE Healthcare, Pittsburgh PA, USA). Then, after analysis of unmodified or washed biochar powders, these were $\mathrm{pH}$ adjusted to match the $\mathrm{pH}$ of peat $(\mathrm{pH}$ 7.4 ) in a 3:1 (v:v) water slurry using small amounts of either $\mathrm{CaCO}_{3}$ or $5 \% \mathrm{HCl}$, and dried at $60^{\circ} \mathrm{C}$ in an oven (Fisher Isotemp, Pittsburgh, PA, USA).

A number of clay-amended biochar carriers were also prepared in order to examine the effects of a having a greater proportion of submicron water holding pores created from clay particles adhering to the biochar powders. These carriers were made from feedstocks that were mixed with calcium $(\mathrm{Ca})$ montmorillonite (Ca-rich montmorillonite STx-1b, Gonzales County, TX, obtained from the Clay Minerals Society, Purdue University, West Lafayette IN, USA) and goethite (goethite of origin Kaluga, Russia, Rublev Colours, Grandville, MI, USA). Ground feedstocks $(2 \mathrm{~mm})$ were mixed with these clays to create $30 \%, 50 \%$, and $100 \%(\mathrm{w}: \mathrm{w})$ clay:biochar mixtures of bagasse, grapevine, and pine feedstocks after accounting for mass loss of feedstocks during pyrolysis (previously tested in the production of unmodified biochars).

\section{Pore size characterization}

Two methods were used to measure mean pore diameters in carriers to cross-validate the measurements. First, mean pore size diameter of biochars was estimated using moisture release under pressure in a pressure-plate extractor apparatus [18]. Two replicate samples of presaturated $(12 \mathrm{~h})$ slurries of inoculant carrier powders were placed in rubber rings of $50 \mathrm{~mm}$ diameter by $7 \mathrm{~mm}$ thickness atop the porous pressure plate. Samples were equilibrated in the pressure extractor and water allowed to escape until pores of mean size $\mathrm{R}$ were emptied according to the model

$$
R=-2 \sigma \cos (\alpha) / P
$$

where $\sigma$ is the surface tension of water, $\alpha$ is the contact angle of water with the biochar surface measuring hydrophobicity, and $\mathrm{P}$ is the equilibrating pressure. By conducting equilibrations at 0.01, 0.03, 0.10, and 1.0 MPa and measuring gravimetric moisture of the equilibrated powders, we were able to measure the gravimetric proportion of pores in size classes defined by equilibrium pressures (with $\alpha=45^{\circ}$, mean pore size thresholds were $30,10,1$ and $0.3 \mu \mathrm{m}$ for these pressures, respectively). We estimated $\alpha$ as $45^{\circ}$ (somewhat hydrophobic) and conducted a sensitivity analysis to demonstrate that the variation in measured mean pore size was driven mostly by the moisture release 
pressure rather than errors in a (see online supplement for additional information and sensitivity analysis, Supplementary Figure S1). These gravimetric measures were converted to volumetric fractions of pores in each pore size diameter class using bulk densities of powders across the range of moisture contents (methods below). An overall mean pore diameter for each microbial carrier was calculated as the weighted average of the center of each pore diameter class (i.e., $0.65,5.5,20 \mu \mathrm{m}$ ).

In addition to moisture release curves, direct measurement of macropore diameters appearing on scanning electron micrographs was used to estimate macropore diameters between 1 and $30 \mu \mathrm{m}$. Ground biochar carriers were mounted on $12.5 \mathrm{~mm}$ aluminum posts with conductive carbon sticky tabs (Electron Microscopy Sciences, Hatfield, PA, USA), coated with gold-palladium, and imaged using a Leica 440 scanning electron microscope (SEM; Leica Corp., Buffalo Grove, IL, USA). Three images of 200-300 $\mu \mathrm{m}$ width were captured per carrier. A random grid of points was overlaid on the images and the resulting images (Supplementary Figure S2 and following) were analyzed using Image-J software [19], using the distance measurement tool in Image-J calibrated to the scale bar. Macropore diameter was measured at 20 grid points per image that were averaged to a mean macropore diameter for the micrograph. The mean diameter from three micrographs was taken as the mean for the carrier.

\section{Carrier bulk density}

Tapped bulk density $(\rho)$ on a dry matter basis across a range of inoculant carrier moisture contents was determined in order to convert gravimetric moisture $(v)$ to volumetric moisture $(\theta)$ [20-22]; more detailed methods in the online supplement]. Biochar carriers with three values of gravimetric moisture, $\left(0.05,0.5\right.$, and approximately $\left.1.0 \mathrm{~g} \mathrm{~g}^{-1}\right)$ were placed in a regular glass cylinder of known length. Mass $(\mathrm{m})$ and volume (V) of the carriers was measured after tapping the cylinder 100 times so that the bulk density could be calculated as:

$$
\rho_{D M}=V / m
$$

A curve fit of $\rho_{\mathrm{DM}}$ against $v$ was then constructed (see Supplementary Table S1) so that gravimetric proportions of different sized pores could be converted to volumetric proportions.

\section{Carrier proximate analysis and chemical properties}

Biochar carriers were assessed for ASTM condensed volatiles and ash content [23]. We used the condensed volatile content reported on an ash-free basis to avoid the confounding effect of ash content on condensed volatile content. Electrical conductivity (EC) of carriers after $\mathrm{pH}$ adjustment and before incubations was determined in a 1:5 $(\mathrm{w}: \mathrm{v})$ aqueous suspension using an Orion model $115 \mathrm{~A}+$ electrical conductivity meter (Thermo Scientific, Waltham, MA, USA). Mineral content of carriers [phosphorus $(\mathrm{P})$, calcium $(\mathrm{Ca})$, magnesium $(\mathrm{Mg})$, potassium $(\mathrm{K})$, sodium $(\mathrm{Na})$, iron $(\mathrm{Fe})$, and aluminum $(\mathrm{Al})]$ was measured using chemical digestion followed by inductively coupled plasma - atomic emission spectroscopy (ICP-AES) as detailed in Enders and Lehmann [24].

\section{Incubation trial preparation and assessment}

All incubation trials below used similar procedures, and were initiated by mixing a microbial broth with $\mathrm{pH}$-adjusted, autoclaved carrier powders in glass vials (further detail in the online supplement). Rhizobium tropici strain CIAT 899 (USDA ARS National Rhizobium Germplasm Collection, Beltsville, MD, USA) was transferred to autoclaved, cooled yeast extract mannitol (YEM) broth containing 10 $\mathrm{g} \mathrm{L}^{-1}$ mannitol, $2 \mathrm{~g} \mathrm{~L}^{-1}$ yeast extract and mineral nutrients as follows with units of $\mathrm{mg} \mathrm{L}^{-1}: 500 \mathrm{~K}_{2} \mathrm{HPO}_{4}, 200 \mathrm{NaCl}, 100 \mathrm{CaSO}_{4} \cdot 2 \mathrm{H}_{2} \mathrm{O}, 200$ $\mathrm{MgSO}_{4} \cdot 7 \mathrm{H}_{2} \mathrm{O}, 10 \mathrm{Fe}-\mathrm{EDTA}, 1 \mathrm{H}_{3} \mathrm{BO}_{3}, 1 \mathrm{ZnSO}_{4}, 0.5 \mathrm{CuSO}_{4} \cdot 5 \mathrm{H}_{2} \mathrm{O}, 0.5$ $\mathrm{MnCl}_{2} \cdot 4 \mathrm{H}_{2} \mathrm{O}, 0.1 \mathrm{Na}_{2} \mathrm{MoO}_{4} \cdot 2 \mathrm{H}_{2} \mathrm{O}$. The broth was then incubated at $30^{\circ} \mathrm{C}$ for $48 \mathrm{~h}$ so that the abundance of $R$. tropici in the broth would reach between $10^{7}$ and $10^{8}$ colony forming units $\mathrm{mL}^{-1}$ (CFU $\mathrm{mL}^{-1}$ ). Carrier powders were weighed into amber $20 \mathrm{~mL}$ screw-top bottles with rubber septa lids fitted with a $4 \mathrm{~mm}$ diameter glass fiber filter vent (Whatman GF/A, $1.6 \mu \mathrm{m}$ nominal pore size, GE Healthcare Life Sciences, Pittsburgh, PA, USA) to allow gas exchange. After autoclaving, we adjusted the moisture of the biochar and press mud carriers using water and inoculant broth so that pores with a diameter of $10 \mu \mathrm{m}$ and below would be filled. For the peat control carrier an industry standard of $40 \%$ gravimetric moisture was used (see Supplementary Table S1 for moisture contents with $10 \mu \mathrm{m}$ pores filled for all carriers). All carriers received the same initial concentration of bacteria in broth. Bottles were then incubated at $27^{\circ} \mathrm{C}$ under humid conditions to slow moisture loss. The drying trial was run in duplicate with a repeated-measures design, while all other experiments were run in triplicate in a randomized complete block design.

Bacterial abundance in the carriers was assessed with drop plates [25]. A $300 \mathrm{mg}$ subsample of each carrier material was aseptically diluted in $30 \mathrm{~mL}$ of sterile water for an initial $10^{-2}(\mathrm{w}: \mathrm{v})$ dilution. Gravimetric water contents $\left(105^{\circ} \mathrm{C}\right)$ were also measured to express bacterial abundances on a dry-matter basis. Sequential ten-fold dilutions in sterile water were then carried out to reach a $10^{-6}$ dilution. Single aliquots of $30 \mu \mathrm{L}$ from the $10^{-2}$ through $10^{-6}$ dilutions were incubated on yeast mannitol agar (YMA, same nutrient content as the above mentioned broth plus $15 \mathrm{~g} \mathrm{~L}^{-1}$ agar). After $\sim 2 \mathrm{~d}$ growth of colonies at $30^{\circ} \mathrm{C}$ and again at $\sim 4 \mathrm{~d}$, colonies of $R$. tropici were counted. Dilutions that resulted in between 20 and 600 colonies were used to calculate the bacterial abundance in the carrier.

\section{Preliminary trials to improve bacterial survival: highest treatment temperature (HTT), feeding rate, and clay addition}

To establish an adequate pyrolysis temperature of biochar for use as a carrier in the following trials, we compared a mixed hardwood carrier pyrolyzed at $450^{\circ} \mathrm{C}$ and $700^{\circ} \mathrm{C}$ HTT. We also tested corresponding biochars washed with either acetone or $1 \% \mathrm{HCl}$ (see above) to test the effects of removal of acetone-soluble condensed volatile matter and ash mineral nutrients, respectively, independent of pyrolysis temperature. We then also assessed the optimal rates of broth nutrient concentrations and the degree of nutrient limitation of R. tropici applied to biochar from three feedstocks (grapevine, bagasse, and pine). The standard broth concentration (above) was used (1x treatment) in both an unmodified carrier and one washed (extracted, thus EXT) with both acetone and $1 \% \mathrm{HCl}(1 \mathrm{x}$ and EXT/1x treatments; see carrier materials above for washing procedure). Three times and six times the broth nutrients ( $3 \mathrm{x}$ and $6 \mathrm{x}$ treatments) were also prepared in an unmodified biochar by augmenting the inoculation broth with additional more concentrated broth added to the carrier material. In addition, we performed preliminary tests of different mixtures of biochar with a 2:1 silicate clay (montmorillonite) and an iron oxide clay (goethite) when clays were introduced into the feedstock prior to pyrolysis to increase the proportion of small pores in the biochar carriers (see carrier materials, above) . We tested both pure pyrolyzed clays and grapevine feedstocks as well as $30 \%, 50 \%$, and 100\% (w:w) mixtures of clay pyrolyzed with grapevine for a two-week incubation. We then tested $50 \%$ (w:w) clay:biochar mixtures with four feedstocks (pine, grapevine, mixed maple, and bagasse) in a one-month incubation. 


\section{Biochar inoculant storage trial}

After these preliminary trials, we used biochar powders from 14 feedstocks (see carrier materials, above) to create widely-ranging chemical properties and mean pore size diameters. These carriers were intended to probe the relationship between chemical and physical properties and the quality of the biochars as a microbial habitat for $R$. tropici in relatively stress-free storage conditions. We used both unmodified biochars and biochars washed with both acetone and $1 \%$ $\mathrm{HCl}$ (above) as well as peat and sugarcane press mud controls, with the idea (confirmed via pressure-plate and micrographic analysis, above) that extraction would change mean macropore diameter relatively little, while changing other chemical properties (e.g., condensed volatile content, mineral content, electrical conductivity) to a greater extent. We used principal components analysis to summarize covariation of the different chemical and physical properties of all the biochars. We then used multiple regressions to combine experiments of identical design (with unmodified, washed, and clay-amended biochars) and elucidate the main determinants of microbial survival on a total of 32 biochar carriers. For the unmodified biochars, we continued the experiment for six months duration in order to assess the utility of these materials as effective carriers for the inoculant industry to replace peat.

\section{Drying trial}

A final trial tested the hypothesis that biochar pore size would alter the survival of $R$. tropici under drying conditions such as might occur in soils. We used grapevine, bagasse, mixed maple, and pine biochar, with and without addition of montmorillonite clay at 50\% (w:w). Added clay was intended to boost the fraction of pores below $0.3 \mu \mathrm{m}$, making these biochars more similar to peat carriers with a high proportion of submicron pores. The carriers along with peat controls were incubated for one month. We then exposed $5 \mathrm{~g}$ of each carrier to drying for $240 \mathrm{~h}$ in sterile, $50 \mathrm{~mL}$ beakers in a sterile biological transfer cabinet, with the beakers left open to the moving air of the transfer cabinet and mixed $2 \mathrm{x}$ per day with a spatula in addition to mixing at each evaluation point. The effect of drying on bacterial survival was assessed using the drop plate method (above) after $1 \mathrm{~h}, 4.5 \mathrm{~h}, 8 \mathrm{~h}, 20 \mathrm{~h}, 80 \mathrm{~h}$, and $240 \mathrm{~h}$. During each assessment a voucher sample of $0.4 \mathrm{~g}$ approximate mass for measuring water activity $\left(\mathrm{A}_{w}\right)$ was placed into $4 \mathrm{~mL}$ sealed glass vials, double bagged to eliminate water loss, refrigerated, and assessed for $\mathrm{A}_{\mathrm{w}}$ and gravimetric water content within $2 \mathrm{~d}$. Water activity was measured using a Decagon AquaLab Series 3 water activity meter after temperature equilibration to room temperature within the vial (Decagon Devices, Pullman, WA, USA).

\section{Statistical methods}

Statistical analyses were conducted in JMP 11.0 (SAS institute, Cary, NC, USA). Analysis of variance (ANOVA) was used to compare treatment means of bacterial abundance on log-transformed data because of lack of homogeneity of variances. We used multiple linear regressions to combine the results from different trials of identical design. Prior to multiple regressions and in order to understand the relations among biochar carrier properties, we carried out dimensional reduction of carrier properties using PCA and factor analysis. We retained components in the PCA with eigenvalues greater than 1 , and used a varimax rotation to define factors of common variation in biochar carrier properties. To avoid "swamping" the PCA with the large number of mineral content variables, we first conducted a PCA and factor analysis on the variables for mineral content, and then used the factor outputs from this PCA in an overall PCA and factor analysis of mineral content, condensed volatile and ash content, macropore diameter, proportion of pores less than $0.3 \mu \mathrm{m}$, and electrical conductivity. In the drying trial we used repeated-measures ANOVA to analyze the changes in bacterial abundance over time in the replicates, and nonlinear regression with exponential models to assess differences between peat, clay-amended biochars, and unmodified biochars in the time course of moisture content and bacterial abundance during drying. In all statistical analyses $p<0.05$ was used as the threshold for a significant effect or significant difference between treatment means.

\section{Results}

\section{Pre-trials: HTT, feeding rates using inoculant broth, and clay addition to biochar carriers}

Pre-trials with biochars pyrolyzed at two different pyrolysis temperatures (HTT) showed that for a hardwood feedstock, a HTT of $700^{\circ} \mathrm{C}$ versus $450^{\circ} \mathrm{C}$ reduced the abundance of $R$. tropici in the incubation $(p<0.05$; Table 1a). Survival was also reduced by washing a $450 \mathrm{C}$ a hardwood biochar with acetone $(p<0.05$; Table 1$)$, and pine, bagasse, and grape biochar carriers with $1 \% \mathrm{HCl}$ and acetone ( $p<0.05$, contrast comparing $1 \mathrm{x}$ broth vs. extracted $+1 \mathrm{x}$ broth biochars Table 1a). Furthermore, adding more broth nutrients and minerals to unmodified biochar did not increase abundance in incubations (Table 1a). R. tropici was therefore not nutrient-limited in the short term (1mo.) in biochar containing condensed volatiles, ash minerals, and a normal 1x YEM broth. Pyrolyzed goethite $\left(450^{\circ} \mathrm{C}\right)$ was unsuitable as a bacterial habitat by itself (Table 1a) and reduced growth of $R$. tropici by approximately $50 \%$ when combined with biochar (Table $1 \mathrm{~b}$ ). CaMontmorillonite by itself was also less suitable than biochar carriers. However, montmorillonite mixed with biomass feedstocks before pyrolysis increased microbial abundance, including a ten-fold increase in abundance between unmodified pine biochar and pine biochar with $50 \%(\mathrm{w}: \mathrm{w})$ montmorillonite (Table $1 \mathrm{~b}$ ). Goethite was converted to a ferromagnetic mineral via pyrolysis, likely hematite, and rendered the biochar particles ferromagnetic.

\section{Factor analyses on biochar carrier properties}

Biochar properties as well as selected properties for peat and sugar cane press mud controls are given in detail in the online supplement (Supplementary Table S1), including chemical properties, bulk density as a function of moisture content, pore fraction below $0.3 \mu \mathrm{m}$, and weighted mean macropore diameter between 0.3 and $30 \mu \mathrm{m}$. The factor analysis of biochar mineral content showed two dominant factors summarizing $74 \%$ of the variation in mineral content (Supplementary Table S2): a first factor that contained minerals arising from plant biomass (e.g., $\mathrm{Ca}, \mathrm{K}, \mathrm{Mg}, \mathrm{P}$ ) and a second factor with other mineral contents dominated by those arising from possible soil inclusion and clay addition to biomass feedstocks to some of the biochar carriers (iron, aluminum) along with their sodium content. A second factor analysis included these two mineral content factors as well as pore diameter and proximate analysis of the carriers and summarized $71 \%$ of the variation in biochar carrier properties (Supplementary Table S3). In this analysis, pore size of both macropores $(0.3-30 \mu \mathrm{m})$ and the proportion of pores smaller than $0.3 \mu \mathrm{m}$ diameter separated into the first rotated factor, along with the mineral factor from the first PCA summarizing plant biomass mineral content.

\section{Rhizobium tropici survival}

For unmodified biochar carriers compared to peat and sugarcane press mud over a six-month storage trial, biochars showed increasingly large differences in their ability to support $R$. tropici (Figure 1). Biochar carriers with the highest ability to maintain the $R$. tropici 
Citation: Vanek SJ, Thies J, Wang B, Hanley K, Lehmann J (2016) Pore-Size and Water Activity Effects on Survival of Rhizobium tropici in Biochar Inoculant Carriers. J Microb Biochem Technol 8: 296-306. doi: 10.4172/1948-5948.1000300

1A: Pyrolysis temperature and acetone extraction, broth nutrient concentration and clay addition pre-trials.

\begin{tabular}{|c|c|c|c|c|c|c|c|c|}
\hline \multicolumn{3}{|c|}{ Pyrolysis temperature pre-trial } & \multicolumn{3}{|c|}{ Feeding rate pre-trial } & \multicolumn{3}{|c|}{ Clay addition pre-trial } \\
\hline \multirow{2}{*}{$\begin{array}{c}\text { Pyrolysis HTT and } \\
\text { extraction treatment } \\
450^{\circ} \mathrm{C} \text { unmodified }\end{array}$} & \multicolumn{2}{|c|}{$\begin{array}{c}\left(C F \cup g^{-1}, \text { dry basis, one }\right. \\
\text { month) }\end{array}$} & \multirow{2}{*}{$\begin{array}{l}\text { Broth concentration and } \\
\text { biochar feedstock } \\
\text { Pine, extracted + 1x } \\
\text { broth }\end{array}$} & \multicolumn{2}{|c|}{$\begin{array}{c}\text { Abundance } \\
\left(C F \cup g^{-1}, \text { dry basis, one }\right. \\
\text { month) }\end{array}$} & \multirow{2}{*}{$\begin{array}{c}\text { \% w:w clay:biochar; } \\
\begin{array}{c}\text { Montmorillonite }(M) ; \\
\text { Goethite }(G)\end{array} \\
\text { Grapevine alone }\end{array}$} & \multicolumn{2}{|c|}{$\begin{array}{c}\text { Mean and separation } \\
\text { (two weeks) }\end{array}$} \\
\hline & $1.54 \mathrm{E}+09$ & A & & $2.85 \mathrm{E}+08$ & CD & & $1.2 \mathrm{E}+10$ & $A B$ \\
\hline \multirow[t]{2}{*}{$\begin{array}{c}450^{\circ} \mathrm{C} \text { acetone } \\
\text { extracted }\end{array}$} & $2.94 \mathrm{E}+06$ & $\mathrm{C}$ & Pine, $1 x$ broth & $3.21 \mathrm{E}+09$ & $\mathrm{BC}$ & Grapevine+30\% M & $1.5 \mathrm{E}+10$ & $A B$ \\
\hline & & & Pine, 3x broth & $3.39 E+09$ & $\mathrm{BC}$ & Grapevine $+50 \% \mathrm{M}$ & $1.6 \mathrm{E}+10$ & $A$ \\
\hline $700^{\circ} \mathrm{C}$ unmodified & $1.92 \mathrm{E}+07$ & $\mathrm{BC}$ & Pine, $6 x$ broth & $2.86 \mathrm{E}+09$ & $\mathrm{BC}$ & Grapevine+100\% M & $1.9 \mathrm{E}+10$ & $A$ \\
\hline \multirow[t]{2}{*}{$\begin{array}{c}700^{\circ} \mathrm{C} \text { acetone } \\
\text { extracted }\end{array}$} & $1.06 \mathrm{E}+08$ & B & Grapevine, extracted $+1 x$ & $1.22 \mathrm{E}+10$ & $A B$ & $100 \% \mathrm{M}$ & $5.6 \mathrm{E}+08$ & $E$ \\
\hline & & & Grapevine, 1x broth & $1.45 \mathrm{E}+10$ & $A B$ & Grapevine $+30 \%$ G & $4.2 \mathrm{E}+09$ & CD \\
\hline \multirow[t]{6}{*}{ Peat } & $2.95 \mathrm{E}+09$ & $A$ & Grapevine, $3 x$ broth & $1.54 \mathrm{E}+10$ & $A B$ & Grapevine $+50 \%$ G & $6.6 \mathrm{E}+09$ & $\mathrm{BC}$ \\
\hline & & & Grapevine, $6 x$ broth & $2.55 \mathrm{E}+10$ & $A$ & Grapevine $+100 \%$ G & $1.7 E+09$ & $\mathrm{DE}$ \\
\hline & & & Bagasse, extracted $+1 x$ & $6.34 \mathrm{E}+09$ & $A B$ & $100 \%$ G & $\begin{array}{c}\text { Below } \\
\text { detection* }\end{array}$ & $\mathrm{F}$ \\
\hline & & & Bagasse, 1x broth & $8.90 \mathrm{E}+09$ & $A B$ & & & \\
\hline & & & Bagasse, $3 x$ broth & $2.37 \mathrm{E}+09$ & $\mathrm{BC}$ & & & \\
\hline & & & Bagasse, $6 x$ broth & $1.00 \mathrm{E}+04$ & $\mathrm{D}$ & & & \\
\hline
\end{tabular}

1B: Clay addition trial with four feedstocks. Different letters after means indicate significant differences (Tukey's) across rows and columns within the trial.

\begin{tabular}{|c|c|c|c|}
\hline Feedstock & Unmodified & Goethite-amended & Montmorillonite-amended \\
\hline Pine & $8.47 \times 10^{8} \mathrm{C}$ & $1.62 \times 10^{9} \mathrm{BC}$ & $8.46 \times 10^{9} \mathrm{~A}$ \\
\hline Mixed Maple & $2.40 \times 10^{9} \mathrm{ABC}$ & $1.52 \times 10^{9} \mathrm{BC}$ & $5.45 \times 10^{9} \mathrm{AB}$ \\
\hline Bagasse & $5.76 \times 10^{9} \mathrm{AB}$ & $8.82 \times 10^{8} \mathrm{C}$ & $8.11 \times 10^{9} \mathrm{~A}$ \\
\hline Grapevine & $3.50 \times 10^{9} \mathrm{ABC}$ & $1.77 \times 10^{9} \mathrm{BC}$ & $3.21 \times 10^{9} \mathrm{ABC}$ \\
\hline $\begin{array}{c}\text { Contrast values and significance } \\
\text { compared to unmodified biochar, } \\
\text { averaging across feedstocks }\end{array}$ & -- & $1.4 \times 10^{9} \mathrm{vs.} 3.1 \times 10^{9 \dagger}$ \\
$p=0.013^{*}$ & $6.3 \times 10^{9} \mathrm{vs.} 3.1 \times 10^{9 \dagger}$ \\
\hline
\end{tabular}

* Below detection: no counts on drop plates $\left(<1.0 \mathrm{E}+04 \mathrm{CFU} \mathrm{g}{ }^{-1}\right)$

† Point estimates and significance $p$-value of a contrast comparing four goethite-amended biochars to the unmodified biochars, and a contrast comparing four montmorillonite-amended biochars to the unmodified biochars.

Table 1: Results of preliminary trials testing the effect of pyrolysis highest treatment temperature (HTT), acetone extraction, broth nutrient concentration, and clay addition on abundance of Rhizobium tropici in biochar carriers. All units are CFU g-1 after incubation at $27^{\circ} \mathrm{C}$ for the time specified (two or four weeks). 1 a. Impacts of pyrolysis temperature (HTT), acetone extraction, broth nutrient concentration, and clay addition rate. Biochar in the HTT trials was made from mixed hardwood; $1 \mathrm{~b}$. Abundance of Rhizobium tropici after a one-month storage trial in unmodified $450^{\circ} \mathrm{C}$ biochars and in biochars amended with $50 \%$ (w:w) goethite or montmorillonite clay added before pyrolysis. Different letters after means indicate significant differences within each trial (Tukey's test, $p<0.05$ ).

population were a group of hardwood biochars, along with grapevine and sugarcane bagasse. These carriers did not significantly differ from peat or sugarcane press mud in bacterial abundance after six months, although in numerical terms abundance was highest in the peat. These better-performing biochar carriers also contained over $10^{8} \mathrm{CFU} \mathrm{g}{ }^{-1} R$. tropici after six months (dotted horizontal line on Figure 1), an industry standard for rhizobia carriers after six months storage.

Pore size based on moisture release was strongly and significantly correlated to visible macropore diameters obtained from scanning electron micrographs, increasing the level of confidence in pressure plate assessments of pore size for this set of biochars (Figure 2; $r=0.80$, $p<0.0001)$. Peat had markedly higher pore volume in pores less than 0.3 $\mu \mathrm{m}$ diameter $\left(0.31 \mathrm{~mL} \mathrm{~mL}^{-1}\right.$ for peat vs. 0.03 to $0.09 \mathrm{~mL} \mathrm{~mL}^{-1}$ range for biochars, see Supplementary Table S1). In a multiple regression analysis of $R$. tropici abundance for the six-month storage trial, macropore diameter was a significant predictor as a quadratic term in the biochar at all three sampling dates (Table 2), with a maximum abundance at a mean pore diameter of $13.6 \mu \mathrm{m}$ (pressure plate data for pore size) or $10.1 \mu \mathrm{m}$ (micrographic diameter estimates) at one month of biochar storage (Figure 3). In addition, ASTM condensed volatile content on an ash-free basis was a negative predictor of bacterial abundance and, after one month, mineral content from plant biomass (mineral factor 1, Supplementary Table S2) was positively correlated to bacterial abundance. Electrical conductivity (EC) was not a significant predictor of bacterial survival, except for the unmodified water hyacinth biochar which had a very high (outlier) EC of $11.2 \mathrm{mS} \mathrm{cm}^{-1}$ (Supplemental Table S1). There was no bacterial survival on unmodified water hyacinth biochar even after one month and it was therefore removed from the regressions.

\section{Drying trials}

Montmorillonite addition to biochar prior to pyrolysis $(+\mathrm{M}$ biochars; Table 3) improved bacterial survival under drying. Mixing montmorillonite with biomass before pyrolysis increased the proportion of pores with diameters less than $0.3 \mu \mathrm{m}$ (t-test, $8.0 \%$ vs. $5.6 \%$ pores $<0.3$ $\mu \mathrm{m}$ out of total porosity for $+\mathrm{M}$ vs. unmodified biochars, $p<0.05, \mathrm{n}=8$ carriers; see also Supplemental Table S1). Montmorillonite-amended biochars held more water than unmodified biochars in pores $<10 \mu \mathrm{m}$ diameter when the experiment was established two weeks before drying was imposed (Table 3c, and t-test, gravimetric moisture 1.23 vs. 0.80 with $10 \mu \mathrm{m}$ pores filled for $+\mathrm{M}$ vs. unmodified biochars, $p<0.01, \mathrm{n}=8$ carriers). Montmorillonite-amended biochars also dried more slowly than unmodified biochars both in absolute moisture content and as 


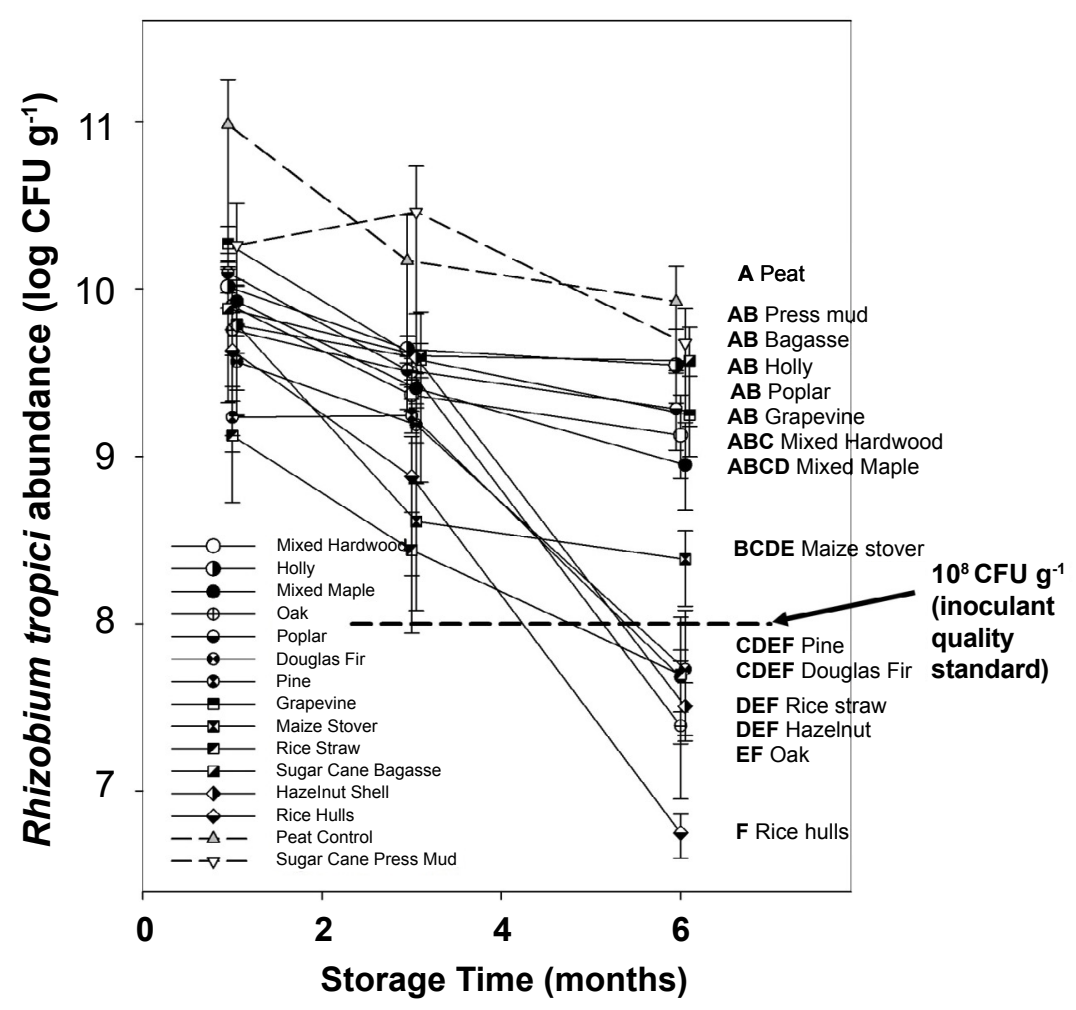

Figure 1: Abundance of Rhizobium tropici in biochar, peat, and sugar cane press mud inoculant carriers during a six month incubation period in a trial under typical moist storage conditions $\left(27^{\circ} \mathrm{C}\right)$. Dotted horizontal line shows an international quality standard for rhizobia inoculant carriers after six months of storage.

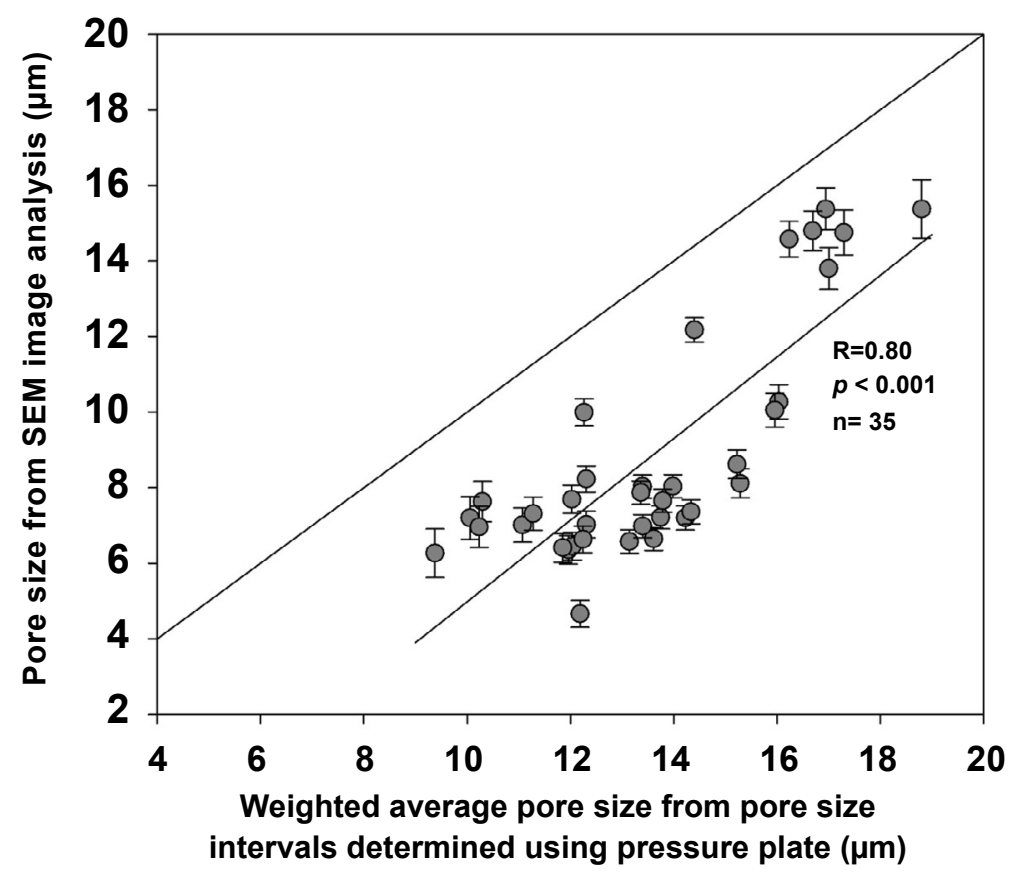

Figure 2: Correlation between pore sizes determined as a weighted average of pore-size intervals measured using moisture release in a pressure-plate apparatus, compared with visual measurement of intra-particle pores on micrographs acquired with a scanning electron microscope (SEM). Diagonal lines show a linear best-fit to the data (lower line through data) and the 1:1 line of correspondence between the two methods (upper line). 
Citation: Vanek SJ, Thies J, Wang B, Hanley K, Lehmann J (2016) Pore-Size and Water Activity Effects on Survival of Rhizobium tropici in Biochar Inoculant Carriers. J Microb Biochem Technol 8: 296-306. doi: 10.4172/1948-5948.1000300

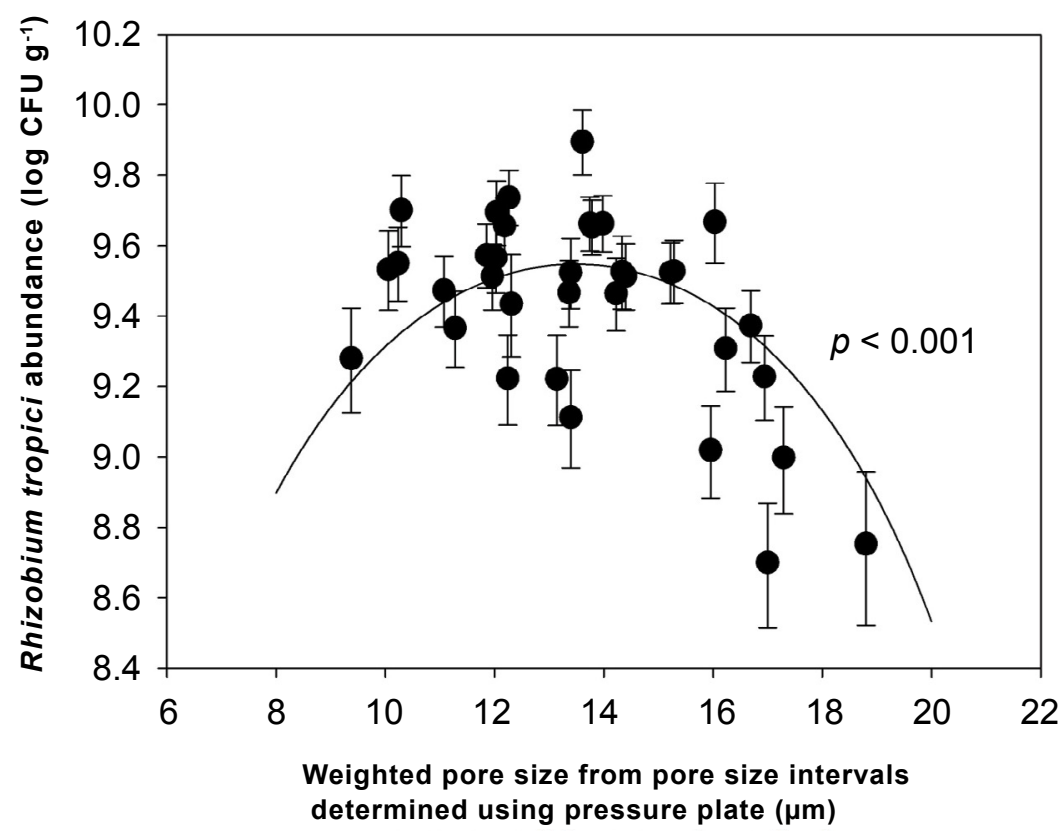

Figure 3: Quadratic dependence of $R$. tropici abundance in biochar on the pore size of biochar carriers. Abundance was measured after one month of storage. Pore size was determined using the weighted average of pore-size intervals measured with moisture release on a pressure plate. $\mathrm{N}=3$ measurements per point. See Table 3 for additional statistical detail.

\begin{tabular}{|c|c|c|c|c|c|c|c|c|c|}
\hline \multirow[b]{3}{*}{ Regression Predictor } & \multicolumn{3}{|c|}{ One month } & \multicolumn{3}{|c|}{ Three months } & \multicolumn{3}{|c|}{ Six months } \\
\hline & \multicolumn{3}{|c|}{32 biochars, $n=3$ per biochar } & \multicolumn{3}{|c|}{14 biochars, $n=3$ per biochar } & \multicolumn{3}{|c|}{14 biochars, $n=3$ per biochar } \\
\hline & $\begin{array}{l}\text { Scaled } \\
\text { slope } \\
\text { estimate* }\end{array}$ & Fratio & $p$-value & $\begin{array}{c}\text { Scaled slope } \\
\text { estimate* }\end{array}$ & Fratio & $p$-value & $\begin{array}{c}\text { Scaled slope } \\
\text { estimate* }\end{array}$ & F ratio & $p$-value \\
\hline $\begin{array}{l}\text { Ash-free condensed } \\
\text { volatiles }\end{array}$ & \multirow[t]{2}{*}{$-2.8 \times 10^{9}$} & \multirow[t]{2}{*}{22.4} & \multirow[t]{2}{*}{$<0.0001^{* * *}$} & \multirow[t]{2}{*}{$-2.1 \times 10^{9}$} & \multirow[t]{2}{*}{36.7} & \multirow[t]{2}{*}{$<0.0001^{* * *}$} & \multirow[t]{2}{*}{$-2.1 \times 10^{9}$} & \multirow[t]{2}{*}{16.7} & \multirow[t]{2}{*}{$0.0003^{* * *}$} \\
\hline$\left(\mathrm{g} \mathrm{g}^{-1}\right)^{*}$ & & & & & & & & & \\
\hline $\begin{array}{c}\text { Mineral Factor } 1(\mathrm{Ca}, \mathrm{Mg} \\
\mathrm{K}, \mathrm{P})\end{array}$ & $2.0 \times 10^{9}$ & 8.5 & $0.0046^{* *}$ & -- & 2.9 & 0.1 & -- & 2.5 & 0.13 \\
\hline $\begin{array}{l}\text { Mean pore size diameter } \\
\text { between } 0.3 \text { and } 30 \mu \mathrm{m} \\
(\mu \mathrm{m})\end{array}$ & & 0.06 & NS & -- & 0.2 & NS & -- & 0.1 & NS \\
\hline $\begin{array}{l}\text { Quadratic of [Mean pore } \\
\text { size diameter between } 0.3 \\
\text { and } 30 \mu \mathrm{m}(\mu \mathrm{m})]\end{array}$ & & 13 & $0.0005^{\star * *}$ & -- & 10.1 & $0.0033^{* *}$ & -- & 7.3 & $0.012^{*}$ \\
\hline $\begin{array}{l}\text { Electrical Conductivity ( } \mu \mathrm{S} \\
\left.\qquad \mathrm{cm}^{-1}\right)^{*}\end{array}$ & & -- & 0.11 & $-1.3 \times 10^{9}$ & 4.5 & $0.04^{*}$ & $-1.2 \times 10^{9}$ & 4.0 & 0.06 \\
\hline Block & -- & 7.5 & $<0.0001^{*}$ & -- & 0.2 & NS & -- & 0.9 & NS \\
\hline
\end{tabular}

Table 2: Multiple regression analysis of Rhizobium tropici strain CIAT 899 abundance in biochar carriers in three evaluations over a six-month trial at $27^{\circ} \mathrm{C}$. A full complement of unmodified, acetone and $1 \% \mathrm{HCl}$-washed, and clay-amended biochars were used in the first regression while those at three and six months used the unmodified biochars only. Significance of regression terms are indicated by ${ }^{*}, p<0.05 ;{ }^{* *}, p<0.01 ;{ }^{* * *}, p<0.001$; and NS, not significant.

\begin{tabular}{|c|c|c|c|c|c|c|}
\hline Time drying & $1 \mathrm{~h}$ & $4.5 \mathrm{~h}$ & $8 \mathrm{~h}$ & $30 \mathrm{~h}$ & $80 \mathrm{~h}$ & $240 \mathrm{~h}$ \\
\hline 3a. Bacterial abundance & \multicolumn{6}{|c|}{ R. tropici abundance $\left(\times 10^{8} \mathrm{CFU} \mathrm{g}^{-1}\right)$} \\
\hline Bagasse & $190(49)$ & $166(44)$ & $140(38)$ & $143(38)$ & $14(4.9)$ & $1.7(0.7)$ \\
\hline Bagasse $+M$ & $246(62)$ & $255(64)$ & $183(48)$ & $253(64)$ & $42(13)$ & $3.9(1.5)$ \\
\hline Grapevine & $218(56)$ & $239(61)$ & $131(35)$ & $55(16)$ & $11(3.7)$ & $2.0(0.8)$ \\
\hline Grapevine + M & $227(58)$ & $267(67)$ & $155(41)$ & $189(49)$ & $12(4.3)$ & $11(3.7)$ \\
\hline Maple & $188(49)$ & $202(52)$ & $123(33)$ & $35(11)$ & $2.3(1.0)$ & $0.6(0.3)$ \\
\hline Maple + M & $214(55)$ & $265(67)$ & $189(49)$ & $223(57)$ & $36(11)$ & $3.5(1.4)$ \\
\hline Pine & $106(29)$ & $104(29)$ & $64(19)$ & $10(3.4)$ & $3.0(1.2)$ & $0.2(0.1)$ \\
\hline Pine $+M$ & $208(54)$ & $270(68)$ & $177(46)$ & $218(56)$ & $27(8.5)$ & $2.7(1.1)$ \\
\hline Peat & $394(95)$ & $444(106)$ & $170(45)$ & $115(31)$ & $33(10)$ & $3.6(1.4)$ \\
\hline Significance of clay addition & NS & ** & ** & $* * *$ & $* * *$ & $\star * *$ \\
\hline
\end{tabular}


Citation: Vanek SJ, Thies J, Wang B, Hanley K, Lehmann J (2016) Pore-Size and Water Activity Effects on Survival of Rhizobium tropici in Biochar Inoculant Carriers. J Microb Biochem Technol 8: 296-306. doi: 10.4172/1948-5948.1000300

\begin{tabular}{|c|c|c|c|c|c|c|c|}
\hline \multicolumn{2}{|c|}{$\begin{array}{c}\text { Significance of difference } \\
\text { between clay-amended biochars } \\
\text { and peat }\end{array}$} & * & * & NS & ** & NS & NS \\
\hline \multicolumn{2}{|c|}{ 3b. Water activity } & \multicolumn{6}{|c|}{ Water activity $\left(\mathrm{A}_{\mathrm{w}}\right)$} \\
\hline \multicolumn{2}{|c|}{ Bagasse } & $0.990(0.01)$ & $0.990(0.01)$ & $0.986(0.01)$ & $0.792(0.05)$ & $0.325(0.05)$ & $0.071(0.03)$ \\
\hline \multicolumn{2}{|c|}{ Bagasse $+M$} & $0.990(0.01)$ & $0.990(0.01)$ & $0.991(0.01)$ & $0.984(0.01)$ & $0.497(0.06)$ & $0.066(0.03)$ \\
\hline \multicolumn{2}{|c|}{ Grapevine } & $0.989(0.01)$ & $0.986(0.01)$ & $0.982(0.02)$ & $0.493(0.06)$ & $0.331(0.05)$ & $0.071(0.03)$ \\
\hline \multicolumn{2}{|c|}{ Grapevine + M } & $0.990(0.01)$ & $0.989(0.01)$ & $0.988(0.01)$ & $0.964(0.02)$ & $0.405(0.06)$ & $0.081(0.03)$ \\
\hline \multicolumn{2}{|c|}{ Maple } & $0.990(0.01)$ & $0.989(0.01)$ & $0.983(0.01)$ & $0.513(0.06)$ & $0.312(0.05)$ & $0.066(0.03)$ \\
\hline \multicolumn{2}{|c|}{ Maple + M } & $0.990(0.01)$ & $0.990(0.01)$ & $0.988(0.01)$ & $0.981(0.02)$ & $0.400(0.06)$ & $0.072(0.03)$ \\
\hline \multicolumn{2}{|c|}{ Pine } & $0.985(0.01)$ & $0.988(0.01)$ & $0.981(0.02)$ & $0.363(0.06)$ & $0.316(0.05)$ & $0.068(0.03)$ \\
\hline \multicolumn{2}{|c|}{ Pine $+M$} & $0.990(0.01)$ & $0.992(0.01)$ & $0.991(0.01)$ & $0.982(0.02)$ & $0.413(0.06)$ & $0.067(0.03)$ \\
\hline \multicolumn{2}{|c|}{ Peat } & $0.987(0.01)$ & $0.941(0.03)$ & $0.895(0.04)$ & $0.437(0.06)$ & $0.310(0.05)$ & $0.070(0.03)$ \\
\hline \multicolumn{2}{|c|}{ Significance of clay addition } & NS & NS & NS & 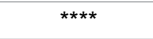 & ** & NS \\
\hline \multicolumn{2}{|c|}{$\begin{array}{c}\text { Significance of difference } \\
\text { between clay-amended biochars } \\
\text { and peat }\end{array}$} & NS & * & *** & $* * * *$ & NS & NS \\
\hline \multicolumn{8}{|c|}{ 3c. Moisture content } \\
\hline \multicolumn{2}{|c|}{$\begin{array}{l}\text { Carrier and Initial moisture } \\
\text { content to fill } 10 \mu \mathrm{m} \text { pores }\end{array}$} & \multicolumn{6}{|c|}{ gravimetric water content $\left(\mathrm{g} \mathrm{g}^{-1}\right)$} \\
\hline Bagasse & 0.92 & $0.65(0.03)$ & $0.55(0.03)$ & $0.39(0.03)$ & $0.10(0.03)$ & $0.06(0.03)$ & $0.05(0.03)$ \\
\hline Bagasse $+M$ & 1.21 & $1.08(0.03)$ & $0.86(0.03)$ & $0.59(0.03)$ & $0.35(0.03)$ & $0.09(0.03)$ & $0.05(0.03)$ \\
\hline Grape & 0.79 & $0.59(0.03)$ & $0.48(0.03)$ & $0.31(0.03)$ & $0.09(0.03)$ & $0.09(0.03)$ & $0.04(0.03)$ \\
\hline Grape + M & 1.15 & $0.85(0.03)$ & $0.79(0.03)$ & $0.58(0.03)$ & $0.25(0.03)$ & $0.09(0.03)$ & $0.05(0.03)$ \\
\hline Maple & 0.87 & $0.59(0.03)$ & $0.55(0.03)$ & $0.31(0.03)$ & $0.08(0.03)$ & $0.07(0.03)$ & $0.04(0.03)$ \\
\hline Maple + M & 1.38 & $1.05(0.03)$ & $0.91(0.03)$ & $0.74(0.03)$ & $0.31(0.03)$ & $0.09(0.03)$ & $0.04(0.03)$ \\
\hline Pine & 0.65 & $0.42(0.03)$ & $0.33(0.03)$ & $0.18(0.03)$ & $0.08(0.03)$ & $0.06(0.03)$ & $0.06(0.03)$ \\
\hline Pine $+M$ & 1.17 & $0.95(0.03)$ & $0.84(0.03)$ & $0.63(0.03)$ & $0.31(0.03)$ & $0.09(0.03)$ & $0.04(0.03)$ \\
\hline Peat & 0.65 & $0.64(0.03)$ & $0.43(0.03)$ & $0.33(0.03)$ & $0.18(0.03)$ & $0.15(0.03)$ & $0.10(0.03)$ \\
\hline \multicolumn{2}{|c|}{ Significance of clay addition } & $* * * *$ & $* \star \star *$ & $* * * *$ & $* \star \star \star *$ & NS & NS \\
\hline \multicolumn{2}{|c|}{$\begin{array}{c}\text { Significance of difference } \\
\text { between clay-amended biochars } \\
\text { and peat }\end{array}$} & $* * * *$ & $* * * *$ & $* * * *$ & ** & NS & NS \\
\hline
\end{tabular}

Z

Table 3: Microbial abundance normalized to water content, water activity, and gravimetric water content for biochar and peat carriers in a $240 \mathrm{~h}$ dry-down trial comparing clay-amended with non-amended biochars (means with standard errors in brackets, $n=2$ ). Significance of clay-amendment across the four biochar feedstocks, as well as difference between montmorillonite-amended $(+\mathrm{M})$ and peat carriers, are given at the base of each column. Significance of regression terms are indicated by ${ }^{*}, p<0.05$; ${ }^{* *}, p<0.01$; and ${ }^{* * *}, p<0.001$; NS, not significant.

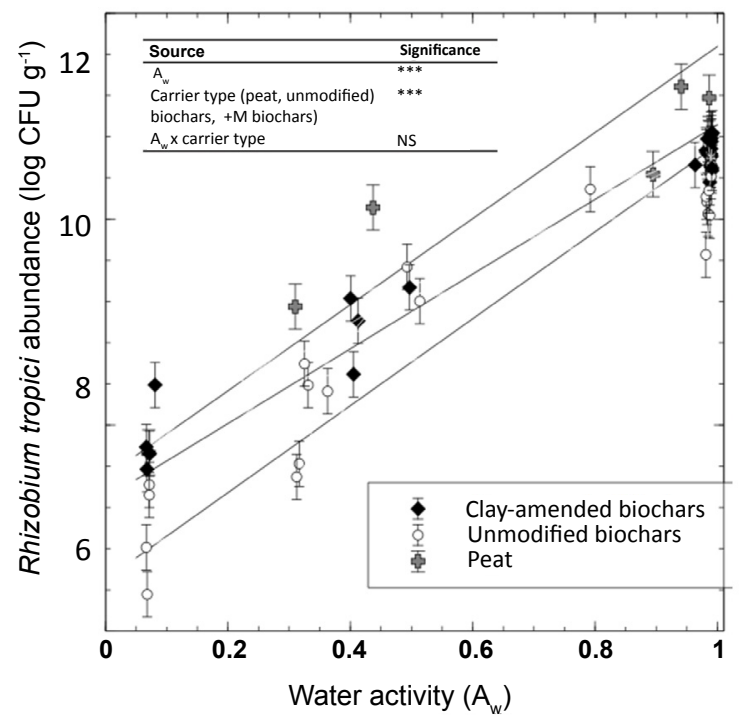

4A: Dependence of survival on water activity $\left(A_{w}\right)$ under drying in peat, unmodified biochar, and clay-amended (montmorillonite) biochar carriers for Rhizobium tropici. Table inset shows statistical significance of $A_{w}$ and the three carrier types. Unmodified and montmorillonite amended $(+\mathrm{M})$ biochars were combined across feedstocks (sugar cane bagasse, grapevine, maple wood, pine wood) to comprise two carrier types in addition to peat.

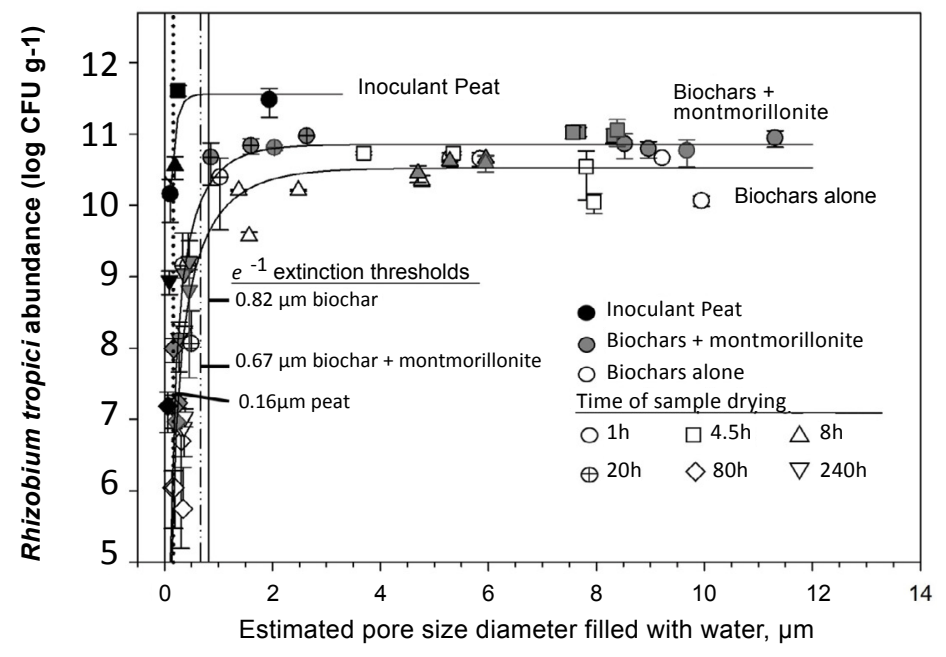

4B: Dependence of $R$. tropici abundance on pore size retaining water under drying of peat, unmodified biochar, and montmorillonite-amended biochar carriers.

Figure 4: A, B: Microbial survival as a function of water activity and estimated pore size filled with water during ten days of drying in a drying experiment. 
a proportion of the initial moisture from the start of the incubation $(p<0.01$; Tables $3 \mathrm{c}$ and 4$)$. However bulk water activity $\left(\mathrm{A}_{\mathrm{w}}\right)$, a predictor of bacterial survival, did not differ between unmodified and $+\mathrm{M}$ biochars for the first $8 \mathrm{~h}$ of drying and at the final dry state at $240 \mathrm{~h}$ (Table 3b).

After $4 \mathrm{~h}$ and until the final sampling with $240 \mathrm{~h}$ of drying, $+\mathrm{M}$ biochars had higher bacterial abundance (Table 3a), in spite of the fact that by $80 \mathrm{~h}$ of drying, initial differences in moisture content between unmodified and $+\mathrm{M}$ biochars had disappeared (Table $3 \mathrm{c}$ ). In addition, for all carriers, bacterial abundance declined with $\mathrm{A}_{\mathrm{w}}$ with a similar slope, but abundance was higher across the range of $A_{w}$ values for $+M$ carriers and peat than for unmodified biochars (Figure 4a; linear regression with categories, peat $>+\mathrm{M}$ biochar $>$ unmodified biochar, $p<0.05)$. In addition, bacterial survival on the carriers was asymptotic in relation to the size of the pores retaining water as drying progressed (Figure $4 \mathrm{~b}$, non-linear regression). Bacterial abundance fell dramatically in both $+\mathrm{M}$ and unmodified biochars once the pores retaining water were just below one micron (Figure $4 \mathrm{~b}$, pore diameters of 0.67 and $0.82 \mu \mathrm{m}$ for the 1/e "shoulder" or extinction threshold of the exponential curve fit to a survival vs. pore diameter plot); just below the minimum size of $R$. tropici cells. However, for peat the extinction threshold indicating survival extended to well below $0.5 \mu \mathrm{m}$ pore size. The parameters of the nonlinear regression fits (Figure $4 \mathrm{~b}$ ) suggested that only peat was significantly different in its behavior with regard to pore diameter compared to unmodified biochars. Montmorillonite-amended biochars therefore had dry-down behavior more similar to biochar than peat, albeit with improved survival for a given bulk-measured $A_{w}$ of the carrier material.

\section{Discussion}

Our experiments are the first systematic exploration testing a large number of biochars as inoculant carriers for rhizobia. We demonstrate that a number of biochars with minimal modification ( $\mathrm{pH}$-adjustment) can equal the performance of a peat "gold standard" carrier made using specialized materials and equipment as well as sugarcane press mud, another viable alternative material. We identify physical and chemical characteristics likely to be important in further optimizing biochar inoculant carriers, with a focus on the legume symbiont Rhizobium tropici strain CIAT 899, an elite strain of rhizobia for use with common bean (Phaseolus vulgaris) in tropical soils. The biochar powders that we employed here are representative of both inoculant carrier materials and of the form that natural fire-derived char particles may take after mechanical breakdown in the soil environment. A number of biochars of woody and herbaceous plant origin were good inoculant carriers not statistically different from peat during six months of storage thereby confirming earlier studies that focused on a more limited range of biochars with other inoculant organisms $[10,26]$, or where a single type

\begin{tabular}{|c|c|c|}
\hline & \multicolumn{2}{|c|}{$\begin{array}{c}\text { Exponential Slope parameter b and significance of } \\
\text { difference in comparison to unmodified biochars, for } \\
\text { moisture under drying fitted to Ae } \mathbf{e}^{\mathrm{t}} \text {, } \mathbf{t} \text { in hours }\end{array}$} \\
\hline Type of carrier & $\begin{array}{c}\text { b, Absolute moisture } \\
\text { content (Table 4c) }\end{array}$ & $\begin{array}{c}\text { b, Moisture proportional to } \\
\text { start of experiment }\end{array}$ \\
\hline $\begin{array}{c}\text { Unmodified } \\
\text { biochars }\end{array}$ & $-0.073+/-0.010$ & $-0.073+/-0.008$ \\
\hline $\begin{array}{c}\text { Clay-amended } \\
\text { biochars }\end{array}$ & $-0.042+/-0.003 * *$ & $-0.042+/-0.003 * *$ \\
\hline Peat & $-0.047+/-0.013 \mathrm{NS}$ & $-0.047+/-0.008 \mathrm{NS}$ \\
\hline
\end{tabular}

Table 4: Slope parameters for exponential fitting of absolute moisture of carriers under drying, and moisture relative to initiation of the experiment. Significan differences at the $p<0.01$ level are indicated with ** while NS denotes "not significant". of largely unidentified charcoal was mixed with other materials [7,8,27]. Although peat and a number of biochars were statistically equivalent in our analyses, the point estimates of survival in biochar were lower than those for both peat and sugarcane press mud, suggesting that biochars could be further improved in their performance as carriers. The sterilization of biochar during pyrolysis is a promising aspect of these potential carrier materials, if sterility can be maintained before colonization of the biochar, for example via aseptic $\mathrm{pH}$-adjustment or precise tuning of biochar $\mathrm{pH}$ using treatments or additives prior to pyrolysis or process conditions.

\section{Nutrient and mineralizable carbon effects}

Both peat and sugarcane press mud likely have a greater proportion of mineralizable carbon in them based on data for plant residue and peat land decomposition versus published residence times for biochar [28]. Greater amounts of easily mineralizable carbon in peat and sugarcane press mud that is likely available to bacteria over time in these carriers suggests that biochars could be improved still further for longer storage by augmenting the broth nutrients typically added to standard inoculant carriers, although we saw no effect of augmenting broth in a one-month incubation. The decrease in abundance in acetone-treated biochar pyrolyzed at $450^{\circ} \mathrm{C}$ versus unmodified hardwood biochar, as well as growth promotion by acetone-soluble organic matter seen in other research for $R$. tropici in pure cultures [29] suggests that a fraction of the biochars themselves could provide a readily mineralizable carbon substrate for bacteria living on biochar carriers. This is plausible in spite of the negative correlation between ASTM condensed volatile matter on rhizobial abundance in our main carrier trial, since acetonesoluble and ASTM condensed volatile matter likely contain different fractions of either toxic or nutrient substances. Beyond these crudely defined measures of labile carbon on biochar, more focused research is needed to test chemically identifiable classes of substances in PyOM as substrates for or toxins to microbial growth [27].

The storage trial with a large number of biochars confirmed our hypothesis that chemical composition was important in determining the quality of biochar inoculant carriers, with a positive influence of mineral content derived from plant nutrients. The fact that plantderived ash nutrients in the biochar such as $\mathrm{K}, \mathrm{Mg}$ and $\mathrm{P}$ were associated with greater bacterial survival on biochar is not surprising, since these nutrients are required by bacteria and usually present in broth preparations designed to support rhizobia in other inoculant carriers. It is therefore puzzling that our preliminary broth nutrient concentration rate trial showed no response to increasing the amounts of these same mineral nutrients in broth applied to a number of biochars (including both high- and low- mineral content biochars). However, our broth concentration study was not designed to measure mineral limitation specifically, and the impact of increasing mineral nutrient content with increasing broth rates could have been confounded with or obscured by increasing the concentrations of yeast extract and mannitol, and thus $\mathrm{C}$ availability.

\section{Pore sizes as a determinant of microbial abundance}

Mean macropore size (i.e., of 0.3 to $30 \mu \mathrm{m}$ diameter pores) played a surprisingly strong role in determining the population of $R$. tropici supported by the biochar carrier, even one month into the trial where nutrient and water stress were presumably not limiting bacterial survival. This result is, however, in rough agreement with earlier work in which porous matrices and adsorption of bacterial cells were studied: Messing and Opperman [15] and Nishiyama et al. [30] found for fritted glass that maximum cell densities occurred at pore dimensions of 
approximately two to four times the largest bacterial cell dimension, while Samonin and Elikova [31] found an adsorption maximum for Acinetobacter of two to five times the cell dimension. We found for $R$. tropici in biochar a maximum bacterial density at the high end of these ranges at a mean pore diameter of between 10 and $15 \mu \mathrm{m}$, just greater than four times the maximum dimension of $R$. tropici $(2.5-3.0 \mu \mathrm{m})$. Our findings differ more dramatically from those of Hale et al. [10] who found that biochar carriers with $36 \mu \mathrm{m}$ pore opening size was predictive of the highest bacterial density of Enterobacter cloacae (1.5-2.0 $\mu \mathrm{m}$ rod length), a morphologically similar bacterium to R. tropici. However, the cited study did not verify pore size diameter measurements with two methods and was less complete in measuring biochar pore size, with only five of ten biochars assessed. Based on our relatively exhaustive assessment of pore size as well as finding that $R$. tropici maintained high levels of survival in the drying trial until the pores emptied by drying were on average the size of this bacterium, our study supports the idea that a maximum of bacterial density in biochars under incubation is likely to occur somewhere between 5 and $15 \mu \mathrm{m}$ for bacteria of the size we used. Two opposite trends likely determine this maximum: for a porous material, the internal colonizable surface of water-filled and water-coated macropores increases with decreasing pore size, proportional to one over the pore size, but is also subject to a lower limit due to the impossibility of bacteria inhabiting pores or moving through pore throats that are smaller than their cell dimensions (e.g. $0.3 \mu \mathrm{m}$ ). In future work, a larger number of organisms with a range of sizes could be used to determine whether such an optimum pore size scales with the size of the organism as found in fritted glass by Messing and Opperman [15]. More generally, our results are consistent with the fact that macropores dominate the pore volume of biochars [32] as well as other work and theory [12] suggesting that non-spore forming bacteria, such as Rhizobium, survive at solid-liquid interfaces as components of water films that are retained within porous materials such as biochar and soil. The pore size for maximal survival around $10 \mu \mathrm{m}$ that we observed is relevant for the pore sizes that are filled in moist unsaturated powders that are typical of inoculant carriers. Subject to further research, this result on microbe-pore relations for organic matter could be relevant to moist, non-saturated soils, where $10 \mu \mathrm{m}$ pores are emptied at just below field capacity.

\section{Improvement of microbial water relations with clay additions}

The drying trial confirmed our hypothesis that increasing the proportion of small pores in biochar using clay promoted microbial survival under drying. This may be explained by the fact that the clay-amended biochars held more water within pores $<10 \mu \mathrm{m}$ under the starting conditions of the trial (i.e., standardized to similar water potential) and therefore maintained a higher water content and water activity for longer during the dry-down period. Nevertheless, even at the end of drying, when water content and water activity did not differ between the montmorillonite-amended and unmodified biochars, survival was still higher in the clay-amended biochars by a ratio of between two and eleven times, and statistically not different between montmorillonite-amended biochars and the peat standard. Therefore, clay amendment of a wide variety of biochars before pyrolysis with appropriate clays such as montmorillonite used here is a promising way to improve performance of the carriers under dry-down, with both clay and biomass sterilized by the pyrolysis process.

Meanwhile, the progression of bacterial survival related to the size of pores filled (Figure 4b) showed that montmorillonite-amended biochar still behaved substantially similarly to non-amended biochar in terms of pore sizes filled and the way that this affected microbial survival: survival fell significantly when the pores filled with water were smaller than the size of a bacterial cell. Peat behaved in a contrasting way, in which the bacteria seemed to be able to survive using water in pores smaller than themselves. One way to explain this finding would be the large fraction of pores $<0.3 \mu \mathrm{m}$ in peat, suggesting that waterfilled pore necks $<0.3 \mu \mathrm{m}$ in diameter are common in peat (see also supplementary online material for images of peat carriers). These pore neck sites would provide spatial niches for microbes to attach and exist within adhered films connected to, but not inside, the water in these small pores. In biochars, meanwhile (whether unmodified or clayamended), microbial niches are likely found in water films on the inside surfaces of macropores that predominate in pyrolyzed biomass, and likely with an optimal diameter of $\sim 10 \mu \mathrm{m}$, at least for $R$. tropici. These pore niches would be associated with water films or indeed, water filling that would support the growth of bacteria. The addition of clay may not change the basic behavior of these pores but could condition them and make them marginally more habitable under dry-down because of niches where clay micro-aggregates adhere inside of or adjacent to macropores and supply small additional amounts of tightly bound water to adhered bacteria under dry-down. This explanation is supported by micrographs showing the added clay in these biochars as an irregular distribution of crumbs encrusted sporadically to the biochar pores, rather than evenly coating the pore surfaces (see supplementary online materials). Cryomicroscopy and other SEM methods should be used in future work to understand the configuration of adhered bacteria in pores and confirm the existence of "unsaturated biofilms" [12] in microbial carriers. Understanding the performance of biochars amended with different clays, and their impact on bacterial survival under stress fosters better understanding of bacterial relationships with biochar in soils, where the interface between clays and particulate organic matter, more generally, and biochar or fire-derived chars, in particular, likely provide hospitable niches for soil biota during drying [33,34].

\section{Conclusion}

Our work demonstrated that some biochars could replace peat and other biomass-based inoculant carriers, to allow for more broad-based and less expensive carrier production. We also point the way towards strategies to improve the performance of these carriers by adjusting the pore size and chemical composition of these biochars with feedstock choice and clay amendment. The importance of pore size and clay-biochar assemblages suggest further hypotheses about the relationship between bacteria and their microhabitats in soils that could be tested in future research. Such research could include longer-term field trials that capture changes in biochar surface properties including oxidation and leaching of biochars, pore-filling, and pore-conditioning via movement of soil water, organic matter, and clay components under field soil conditions.

\section{Acknowledgement}

The authors appreciate the financial support by the NSF-Basic Research for Enabling Agricultural Development program (BREAD grant number IOS-0965336) and the Foundation des Fondateurs. Any opinions, findings and conclusions or recommendations expressed in this material are those of the authors and do not necessarily reflect the views of the donors. We thank Sara Nason and Akio Enders for help in conducting the experiment and John Grazul, John Hunt, and the Cornell Center for Materials Research for microscopy assistance. This work made use of the Cornell Center for Materials Research Shared Facilities which are gratefully acknowledged and supported through the NSF MRSEC program (DMR-1120296) We also thank the MEA fertilizer company for supplying press mud carrier and several anonymous referees for their valuable comments.

\section{References}

1. Date RA (2001) Advances in inoculant technology: A brief review. Aust J Exp Agr 41: 321-325. 
Citation: Vanek SJ, Thies J, Wang B, Hanley K, Lehmann J (2016) Pore-Size and Water Activity Effects on Survival of Rhizobium tropici in Biochar Inoculant Carriers. J Microb Biochem Technol 8: 296-306. doi: 10.4172/1948-5948.1000300

2. Daza A, Santamaria C, Rodriguez-Navarro DN, Camacho $M$, Orive $R$, et al (2000) Perlite as a carrier for bacterial inoculants. Soil Biol Biochem 32: 567-572.

3. Stephens JHG, Rask HM (2000) Inoculant production and formulation. Field Crop Res 65: 249-258.

4. Viveganandan G, Jauhri KS (2000) Growth and survival of phosphatesolubilizing bacteria in calcium alginate. Microbiol Res 155: 205-207.

5. Fernandes PI, Rorh TG, de Oliveira PJ, Xavier GR, Rumjanek NG (2009) Polímeros como veículos para formulações de inoculantes rizobianos. Pesqui Agropecu Bras 44: 1184-1190.

6. Anyango B, Keya SO, Balasundaram VR (1985) Assessment of filter mud as a carrier for legume seed inoculants: Physico-chemical properties and Rhizobium phaseoli survival. In Biological Nitrogen Fixation in Africa: Proceedings of the First Conference of the African Association for Biological Nitrogen Fixation Nairobi Rhizobium MIRCEN, Nairobi, Kenya

7. Beck D (1991) Suitability of charcoal-amended mineral soil as carrier for Rhizobium inoculants. Soil Biol Biochem 23: 41-44.

8. ElShafie A, ElHussein A (1991) An evaluation of Rhizobium survival in 2 carriers new to Sudan. Exp Agr 27: 319-321.

9. Saranya K, Santhana P, Kumutha K, French J (2011) Potential for biochar as an alternate carrier to lignite for the preparation of biofertilizers in India. Int $\mathrm{J} \mathrm{Agr}$ Env Biotechnol 4: 167-172.

10. Hale L, Luth M, Crowley D (2015) Biochar characteristics relate to its utility as an alternative soil inoculum carrier to peat and vermiculite. Soil Biol \& Biochem 81: 228-235.

11. Kibunja NC (1985) Agricultural residues as inoculant carriers in Kenya. In Biological Nitrogen Fixation in Africa: Proceedings of the First Conference of the African Association for Biological Nitrogen Fixation, Nairobi Rhizobium MIRCEN, Nairobi, Kenya.

12. Holden PA (2011) How do the microhabitats framed by soil structure impact soil bacteria and the processes that they regulate. ( $\left.1^{\text {st }} \mathrm{Edn}\right)$, Architecture and Biology of Soils: Life in Inner Space, CAB International, Wallingford UK.

13. Ranjard L, Richaume A (2001) Quantitative and qualitative microscale distribution of bacteria in soil. Res Microbiol 152: 707-716.

14. Ruamps LS, Nunan N, Chenu C (2011) Microbial biogeography at the soil pore scale. Soil Biol \& Biochem 43: 280-286.

15. Messing RA, Opperman R (1979) Pore dimensions for accumulating biomass: 1. Microbes that reproduce by fission or by budding. Biotechnol Bioeng 21: 49-58.

16. Zengeni R, Mpepereki S, Giller KE (2006) Manure and soil properties affect survival and persistence of soyabean nodulating rhizobia in smallholder soils of Zimbabwe. Appl Soil Ecol 32: 232-242.

17. Lehmann J, Rillig MC, Thies J, Masiello CA, Hockaday WC, et al. (2011) Biochar effects on soil biota - A review. Soil Biol \& Biochem 43: 1812-1836.
18. Nimmo JR (2004) Porosity and pore-size distribution, Encyclopedia of Soils in the Environment, Elsevier, London.

19. Schneider CA, Rasband WS, Eliceiri KW (2012) NIH Image to ImageJ: 25 years of image analysis. Nat Methods 9: 671-675.

20. Rajkovich S, Enders A, Hanley K, Hyland C, Zimmerman AR, et al. (2012) Corn growth and nitrogen nutrition after additions of biochars with varying properties to a temperate soil. Biol Fert Soils 48: 271-284.

21. World Health Organization (WHO) (2012) Bulk and tapped density of powders

22. American Society for Testing and Materials (ASTM) ASTM B527-15: Standard test method for tap density of metal powders and compounds, ASTM International, West Conshohocken, PA.

23. Enders A, Hanley K, Whitman T, Joseph S, Lehmann J (2012) Characterization of biochars to evaluate recalcitrance and agronomic performance. Bioresour Technol 114: 644-653.

24. Enders A, Lehmann J (2012) Comparison of wet digestion and dry ashing methods for total elemental analysis of biochar. Comm Soil Sci Plan 43: 1042-1052.

25. Hoben HJ, Somasegaran P (1982) Comparison of the pour, spread, and drop plate methods for enumeration of Rhizobium spp. in inoculants made from presterilized peat. Appl Environ Microbiol 44: 1246-1247.

26. Sun D, Meng J, Liang H, Yang E, Huang Y, et al. (2015) Effect of volatile organic compounds absorbed to fresh biochar on survival of Bacillus mucilaginosus and structure of soil microbial communities. J Soil Sediment 15:271-281.

27. Stella D, Sivasakthivelan P (2009) Effect of different organic amendments addition into Azospirillum bioinoculant with lignite as carrier material. Bot Res Internat 2: 229-232

28. Kuzyakov Y, Bogomolova I, Glaser B (2014) Biochar stability in soil: Decomposition during 8 years and transformation as assessed by compoundspecific 14C analysis. Soil Biol Biochem 70: 229-236.

29. Güerena D, Lehmann J, Thies JE, Enders A, Karanja N, et al. (2015) Partitioning the contributions of biochar properties to enhanced biological nitrogen fixation in common bean (Phaseolus vulgaris). Biol Fert Soils 51: 479-491.

30. Nishiyama M, Senoo K, Matsumoto S (1995) Survival of a bacterium in microporous glass in soil. Soil Biol Biochem 27: 1359-1361.

31. Samonin VV, Elikova EE (2004) A study of the adsorption of bacterial cells on porous materials. Mikrobiologiia 73: 810-816.

32. Brewer CE, Chuang VJ, Masiello CA, Gonnermann H, Gao X, et al. (2014) New approaches to measuring biochar density and porosity. Biomass Bioenerg 66: 176-185.

33. Kong AY, Six J (2012) Microbial community assimilation of cover crop rhizodeposition within soil microenvironments in alternative and conventional cropping systems. Plant Soil 356: 315-330.

34. Ding GC, Pronk GJ, Babin D, Heuer H, Heister K, et al. (2013) Minera composition and charcoal determine the bacterial community structure in artificial soils. FEMS Microbiol Ecol 86: 15-25. 